\title{
Adipose tissue glycogen synthase activation by in vivo insulin in spontaneously insulin-resistant and Type 2 (non-insulin-dependent) diabetic rhesus monkeys
}

\author{
H. K. Ortmeyer, N.L. Bodkin and B.C. Hansen
}

Obesity and Diabetes Research Center, Department of Physiology, School of Medicine, University of Maryland at Baltimore, Baltimore, Maryland, USA

\begin{abstract}
Summary. In skeletal muscle, a defect in the covalent activation of glycogen synthase by insulin has been identified in insulin resistance and in Type 2 (non-insulin-dependent) diabetes mellitus, but a similar defect in insulin action at the adipose tissue has not been demonstrated. We sought to determine whether this defect in insulin action in muscle was also present in the same pathway in adipose tissue. We examined the effect of in vivo insulin on adipose tissue glycogen synthase and phosphorylase activity in normal $(n=11)$, hyperinsulinaemic $(n=8)$, and impaired glucose tolerant and Type 2 diabetic $(n=8)$ rhesus monkeys. Adipose tissue samples were obtained before and during a euglycaemic hyperinsulinaemic clamp. Glycogen synthase fractional velocity, independent and total activities were significantly higher in the insulin-stimulated samples compared to the basal samples in the normal group ( $p<0.05$, respectively). In the hyperinsulinaemic group, however, insulin had no effect
\end{abstract}

on glycogen synthase fractional velocity or independent activity, but did increase the total activity of glycogen synthase and phosphorylase $(p<0.05$, respectively). Furthermore, both the basal and the insulin-stimulated total activities of these two enzymes were significantly greater in the hyperinsulinaemic group as compared to both the normal and the diabetic groups $(p<0.05$, respectively). In the diabetic group, insulin was without effect on glycogen synthase fractional velocity, independent activity or total activity. We conclude that the covalent activation of adipose tissue glycogen synthase by insulin is absent in both obese hyperinsulinaemic and in spontaneously diabetic monkeys.

Key words: Glycogen synthase, glycogen phosphorylase, insulin action, rhesus monkeys, adipose tissue, insulin resistance, Type 2 (non-insulin-dependent) diabetes mellitus, insulin-mediated glucose disposal rates.
Insulin activates glycogen synthase in both muscle and adipose tissue by increasing the ratio of the independent activity of the enzyme to the total activity $[1,2]$. In muscle from many species (including rats, mice, rabbits, monkeys and humans) and in adipocytes prepared from epididymal fat pads from rats, insulin has been shown to exert this effect on glycogen synthase without increasing the total activity of the enzyme [2-16]. In isolated adipocytes prepared from subcutaneous adipose tissue from normal human subjects, however, insulin increased both the independent activity and total activity of glycogen synthase over basal values [17], and this was also found in isolated adipocytes from obese and Type 2 (non-insulin-dependent) diabetic subjects [17]. In contrast to this observation of normal insulin action on glycogen synthase in adipocytes from diabetic humans, insulin activation of skeletal muscle glycogen synthase from humans and from rhesus monkeys with Type 2 diabetes has been shown to be defective [18-23]. Additionally, prior reports have found an absence of [22] or reduced insulin action on skeletal muscle glycogen synthase from insulin-resistant humans $[24,25]$ and monkeys [23] and in first degree relatives of Type 2 diabetic patients [26]. In muscle, therefore, the defect in insulin action on glycogen synthase is an early event, preceding the development of overt diabetes.

Glycogen storage in muscle serves a different purpose from glycogen storage in adipose tissue. In the muscle, glycogen provides energy for contraction, whereas in the adipose tissue, glycogen provides one source of glycerol 3phosphate which is necessary for the esterification of fatty acids to triacylglycerides [27]. It is therefore possible that the effect of insulin on glycogen synthase is differentially regulated in muscle and adipose tissue and that a defect in one tissue may not be present in the other. We hypothesized that a defect in the covalent activation of adipose tissue glycogen synthase in response to insulin would be present in Type 2 diabetic monkeys, but that the activation of adipose tissue glycogen synthase by insulin in obese hyperinsulinaemic monkeys would be either similar to or greater than that in normal monkeys. This hypo- 
thesis was based on earlier findings in non-diabetic obese monkeys that demonstrated normal or enhanced glucose oxidation and lipid synthesis in response to in vitro insulin as compared to normal monkeys, and reduced glucose oxidation and lipid synthesis in diabetic monkeys as compared to pre-diabetic monkeys [28].

We therefore sought to determine in vivo insulin action on total and independent activities of glycogen synthase and on glycogen synthase fractional velocity in subcutaneous abdominal adipose tissue from normal monkeys, from non-diabetic insulin-resistant monkeys, and from Type 2 diabetic monkeys. We also examined the relationship between insulin activation of glycogen synthase in adipose tissue and whole-body insulin-mediated glucose disposal rates and degree of obesity (percent body fat). Activities of glycogen phosphorylase under basal fasting and euglycaemic hyperinsulinaemic clamp conditions were also determined.

\section{Materials and methods}

Rhesus monkeys (Macaca mulatta), under longitudinal study in the Obesity and Diabetes Research Center, were selected for inclusion in the present study $(n=27)$. This group ranged in age from 7 to 25 years and in body weight from 8 to $27 \mathrm{~kg}$. The colony is maintained in accordance with the National Institutes of Health Guide for the Care and Use of Laboratory Animals [29]. All animals were in excellent health and were individually housed and maintained under constant laboratory conditions. They were maintained on either a complete liquid diet (Ensure; Ross Laboratories, Inc., Columbus, Ohio, USA) or Purina Monkey Chow (Purina, St. Louis, Mo., USA). The longitudinal characterization of the monkeys was used to select three groups for the present study; normal monkeys, hyperinsulinaemic monkeys, and monkeys with significantly impaired glucose tolerance, most of which were overtly diabetic. In accord with the prior longitudinal characterization, the animals had been classified into phases associated with the progression to overt diabetes [30]. Group $1(n=11)$ consisted of normal monkeys with fasting plasma glucose less than $4.4 \mathrm{mmol} / \mathrm{l}$ and normal glucose tolerance, previously identified as in phase 1 or 2 [30]. The second group $(n=8)$ included those in the transition between normal and impaired glucose tolerant, who were hyperinsulinaemic (fasting plasma insulin $\geq 718 \mathrm{pmol} / \mathrm{I}$ ) and insulin-resistant (whole-body insulinmediated glucose disposal rates $\leq 7.3 \mathrm{mg} \cdot \mathrm{kg}$ fat-free mass ${ }^{-1} \cdot \mathrm{min}^{-1}$ ) (phases 3-6). The third group $(n=8)$ had progressed to significantly impaired glucose tolerance (glucose disappearance rate, $\mathrm{K}_{\text {Gucose }}$ $<1.6 \% / \mathrm{min}$ ) including six who were overtly diabetic as defined by National Diabetes Data Group criteria (phases 7-9) [31].

The monkeys were not receiving any medication; insulin treatment had not yet been initiated for the diabetic animals.

\section{Procedures}

Procedures requiring less than $2 \mathrm{~b}$ (for example fasting plasma substrate and hormone levels, intravenous glucose tolerance tests and the body fat determinations) were carried out under sedation with ketamine hydrochloride $(10 \mathrm{mg} / \mathrm{kg})$. Glucose disappearance rate $\left(\mathrm{K}_{\mathrm{Glucose}}\right)$ and acute insulin response $(0-10 \mathrm{~min})$ were determined during an intravenous glucose tolerance test as previously described $[30,32,33]$. The euglycaemic hyperinsulinaemic clamp protocol was carried out under fentanyl citrate anaesthesia $(0.01 \mathrm{mg} / \mathrm{kg})$ with succinylcholine $(1 \mathrm{mg} / \mathrm{kg}$ ) used initially, followed by vecuronium bromide $(0.1 \mathrm{mg} / \mathrm{kg})$ for muscle relaxation. Diazepam $(2.5 \mathrm{mg} / \mathrm{dose}$, total of $15 \mathrm{mg}$ ) was given as needed. All monkeys tolerated this procedure well, and there were no adverse effects.

\section{Experimental protocol}

Prior to the initiation of the euglycaemic hyperinsulinaemic clamp, a subcutaneous fat biopsy $(1 \mathrm{~g})$ was obtained from the right abdominal area, placed in phosphate buffer $(\mathrm{pH}=7.5)$ and processed immediately. The euglycaemic hyperinsulinaemic clamp was initiated with a priming infusion of regular pork insulin, followed by continuous insulin infusion $\left(400 \mathrm{mU} \cdot \mathrm{m}^{2}\right.$ body surface area $\left.{ }^{-1} \cdot \mathrm{min}^{-1}\right)$ for $120 \mathrm{~min}$. This dose had been previously determined to produce maximal insulin-stimulated glucose disposal. The rate of infusion of a $20 \%$ glucose solution was adjusted to maintain euglycaemia [32]. Insulinmediated glucose disposal rate was calculated at stable glucose levels of 4.4 to $5.0 \mathrm{mmol} / \mathrm{l}$ for all animals. This insulin infusion rate produced a steady-state plasma insulin concentration of 33,582 \pm $1,488 \mathrm{pmol} / 1$ (mean $\pm \mathrm{SEM}, n=27$ ). The calculation of glucose disposal rate was corrected for fat-free mass as determined by the tritiated water dilution method [34]. During the final 20 min of the euglycaemic clamp, $117 \pm 3$ min (mean $\pm \mathrm{SEM}, n=27$ ) after the onset of the insulin infusion, an additional subcutaneous fat biopsy was obtained from the left abdominal area as indicated above.

The adipose tissue samples were dissected free of blood and obvious connective tissue and placed in a phosphate buffer solution $(\mathrm{pH}=7.5)$. The samples were then centrifuged at $1200 \times \mathrm{g}$ for $5 \mathrm{~min}$ at room temperature, the fat removed, weighed and homogenized ( $20 \%$ weight/volume solution) in a buffer solution containing $50 \mathrm{mmol} / 1$ tricine, $0.1 \%$ 2-mercaptoethanol, $10 \mathrm{mmol} / \mathrm{l}$ EDTA, $100 \mathrm{mmol} / \mathrm{l}$ potassium fluoride and $0.5 \mathrm{mmol} / \mathrm{l}$ phenylmethylsulphonyl fluoride. The homogenate was centrifuged at $8800 \times \mathrm{g}$ for $2 \mathrm{~min}$ at $4^{\circ} \mathrm{C}$.

\section{Assays}

Plasma glucose levels were determined using the Beckman Glucose Analyzer II (Beckman Instruments, Fullerton, Calif., USA) and plasma insulin levels by a double antibody radioimmunoassay [35]. Body fat was determined using tritiated water $(4 \mu \mathrm{Cl} / \mathrm{kg})$ with dilution determined on plasma samples obtained at $1 \mathrm{~h}$ [34].

Glycogen synthase assay. The assay of glycogen synthase was based on the incorporation of uridine $5^{\prime}$-diphospho- $\left[\mathrm{U}-{ }^{14} \mathrm{C}\right]$ glucose into glycogen and activities were expressed as nmol of glucose incorporated into glycogen per min - mg of protein. Activities of glycogen synthase were measured by adding $30 \mu$ of adipose tissue infranatant to $60 \mu \mathrm{l}$ of reaction mixture $(50 \mathrm{mmol} / 1$ Trizma base, $20 \mathrm{mmol} / \mathrm{l}$ EDTA, $87.5 \mathrm{mmol} / \mathrm{l}$ potassium fluoride, $0.2 \mathrm{mmol} / 1$ uridine 5 '-diphosphoglucose, $5000 \mathrm{dpm}$ uridine $5^{\prime}$-diphospho-[U- $\left.{ }^{14} \mathrm{C}\right]$ glucose per nmol/l uridine 5'-diphosphoglucose, and 1\% glycogen). Total glycogen synthase activity and the activity of the independent form of glycogen synthase were measured using glucose 6-phosphate concentrations of 10 mmoll and $0.1 \mathrm{mmol} /$, respectively [36]. The fractional velocity of glycogen synthase was the percent activity in the presence of $0.1 \mathrm{mmol} / /$ glucose 6 -phosphate relative to the activity in the presence of $10 \mathrm{mmol} / \mathrm{l}$ glucose 6 -phosphate. The optimal reaction time $(10 \mathrm{~min})$ was determined by a percent substrate consumption of $30 \%$ or less (mean \pm SEM $9 \pm 1 \%, n=27$ ).

Glycogen phosphorylase assay. The assay of glycogen phosphorylase was based on the incorporation of $\left[\mathrm{U}-{ }^{14} \mathrm{C}\right]$ glucose 1 -phosphate into glycogen and activities were expressed as $\mu \mathrm{mol}$ of glucose incorporated into glycogen per min $\cdot \mathrm{mg}$ of protein. Activities of phosphorylase were measured by adding $60 \mu \mathrm{l}$ of adipose tissue infranatant to $60 \mu \mathrm{l}$ of reaction mixture $(200 \mathrm{mmol} / 1$ potassium fluoride, $100 \mathrm{mmol} / 1$ glucose 1 -phosphate, $27,000 \mathrm{dpm}\left[\mathrm{U}-{ }^{14} \mathrm{C}\right]$ glucose $1-$ phosphate per nmol/l glicose 1-phosphate, and $1 \%$ glycogen). Total 
Table 1. Characteristics of the groups of monkeys studied

\begin{tabular}{|c|c|c|c|}
\hline & $\begin{array}{l}\text { Group } 1 \\
\text { (Normal) }\end{array}$ & $\begin{array}{l}\text { Group } 2 \\
\text { (Hyper- } \\
\text { insulin- } \\
\text { aemic) }\end{array}$ & $\begin{array}{l}\text { Group } 3 \\
\text { (Impaired } \\
\text { glucose tole- } \\
\text { rant/Type } 2 \\
\text { diabetic) }\end{array}$ \\
\hline Phase & $1-2$ & $3-6$ & $7-9$ \\
\hline$n$ & 11 & 8 & 8 \\
\hline Age (years) & $12 \pm 2$ & $15 \pm 2$ & $21 \pm 1^{b, f}$ \\
\hline Body weight (kg) & $12 \pm 1$ & $18 \pm 2^{b}$ & $13 \pm 1^{e}$ \\
\hline Body fat (\%) & $21 \pm 2$ & $29 \pm 2^{\circ}$ & $31 \pm 3^{c}$ \\
\hline $\begin{array}{l}\text { Fasting plasma glucose } \\
(\mathrm{mmol} / \mathrm{l})\end{array}$ & $3.6 \pm 0.1$ & $3.7 \pm 0.1$ & $9.8 \pm 1^{\mathrm{a}, \mathrm{d}}$ \\
\hline $\begin{array}{l}\text { Fasting plasma insulin } \\
(\mathrm{pmol} / \mathrm{l})\end{array}$ & $234 \pm 31$ & $828 \pm 74^{a}$ & $390 \pm 115^{d}$ \\
\hline $\mathrm{K}_{\text {Glucose }}(\% / \mathrm{min})$ & $3.9 \pm 0.3$ & $2.8 \pm 0.2^{b}$ & $1.2 \pm 0.1^{\mathrm{a}, \mathrm{d}}$ \\
\hline $\begin{array}{l}\text { Acute insulin response } \\
\left(\mathrm{pmol} \cdot \mathrm{I}^{-1} \cdot \mathrm{min}^{-1}\right)\end{array}$ & $1440 \pm 322$ & $2520 \pm 560$ & $168 \pm 45^{\mathrm{c}, \mathrm{d}}$ \\
\hline $\begin{array}{l}\mathrm{M}(\mathrm{mg} \cdot \mathrm{kg} \text { fat-free mass } \\
\left.\mathrm{min}^{-1}\right)\end{array}$ & $10.4 \pm 0.9$ & $5.3 \pm 0.5^{\mathrm{a}}$ & $1.7 \pm 0.6^{a_{e}}$ \\
\hline
\end{tabular}

${ }^{\mathrm{a}} p<0.001,{ }^{\mathrm{b}} p<0.01,{ }^{\mathrm{c}} p<0.05$ significantly different from Phases $1-2$; Values shown are mean \pm SEM

${ }^{\mathrm{d}} p<0.001,{ }^{\mathrm{e}} p<0.01,{ }^{\mathrm{f}} p<0.05$ significantly different from Phases 3-6 $\mathrm{M}$, whole-body glucose disposal rates

phosphorylase activity and the activity of the independent (active) form of phosphorylase were measured in the presence of AMP $(3 \mathrm{mmol} / \mathrm{l})$ or in the absence of AMP, respectively. The activity ratio of phosphorylase was the percent activity in the absence of AMP relative to the activity in the presence of $3 \mathrm{mmol} / \mathrm{AMP}$. The optimal reaction time $(180 \mathrm{~min})$ was determined by a percent substrate consumption of $20 \%$ or less (mean \pm SEM $6 \pm 1 \%, n=27$ ).

Protein content was determined in the infranatant using the Bradford assay [37]. Intraassay coefficients of variation of glycogen synthase, phosphorylase and protein were $7 \%, 5 \%$ and $6 \%$, respectively.

\section{Statistical analysis}

Data have been expressed as mean \pm SEM. Comparisons between basal and insulin-stimulated conditions were carried out using the paired Student's $t$-test [38]. Significant group differences were determined by one way analysis of variance and significant $F$ values further tested by the Newman-Keuls multiple comparison method [38]. Pearson's correlation coefficient was used to examine the relationships between key variables [38]. Analysis of covariance was used to identify the contributions, if any, of age and body fat to the group differences [38].

\section{Results}

In vivo characteristics. The 27 monkeys were divided into three groups on the basis of fasting plasma glucose and insulin, and glucose tolerance. Characteristics of each group are shown in Table 1 . The normal and the hyperinsulinaemic groups were both normoglycaemic (fasting plasma glucose concentrations $<4.6 \mathrm{mmol} / \mathrm{l}$ ), while the impaired glucose tolerant/Type 2 diabetic group ranged from 5.8 to
$15.1 \mathrm{mmol} / \mathrm{l}$. Glucose tolerance decreased progressively from the normal to the impaired glucose tolerant/diabetic group. Acute insulin response to intravenous glucose showed an inverted "U" shape previously identified in studies of the longitudinal progression to overt diabetes [33]. Peripheral glucose disposal under euglycaemic clamp conditions (an estimate of peripheral insulin sensitivity) ranged from 16.1 to $0 \mathrm{mg} \cdot \mathrm{kg}$ fat-free mass ${ }^{-1} \cdot \mathrm{min}^{-1}$, progressively decreasing across the three groups, and all groups differed significantly from each other $(p<0.01$, respectively).

Basal and insulin-mediated adipose tissue glycogen synthase activity. The independent activity (upper panel) and total activity (lower panel) of glycogen synthase within and between groups under basal and insulin-stimulated conditions are shown in Figure 1. The fractional velocity of glycogen synthase within and between groups under basal and insulin-stimulated conditions is shown in Figure 2. Only the normal monkeys ( $n=11$ ) had significant activation of glycogen synthase by insulin as measured by both the fractional velocity ( $10 \pm 2$ vs $15 \pm 3 \%, p<0.05$ ) and independent activity of glycogen synthase $(0.7 \pm 0.3 \mathrm{vs}$ $1.4 \pm 0.4 \mathrm{nmol} \cdot \mathrm{min}^{-1} \cdot \mathrm{mg}$ protein ${ }^{-1}, p<0.005$ ) compared to basal activity. The basal and insulin-stimulated frac-
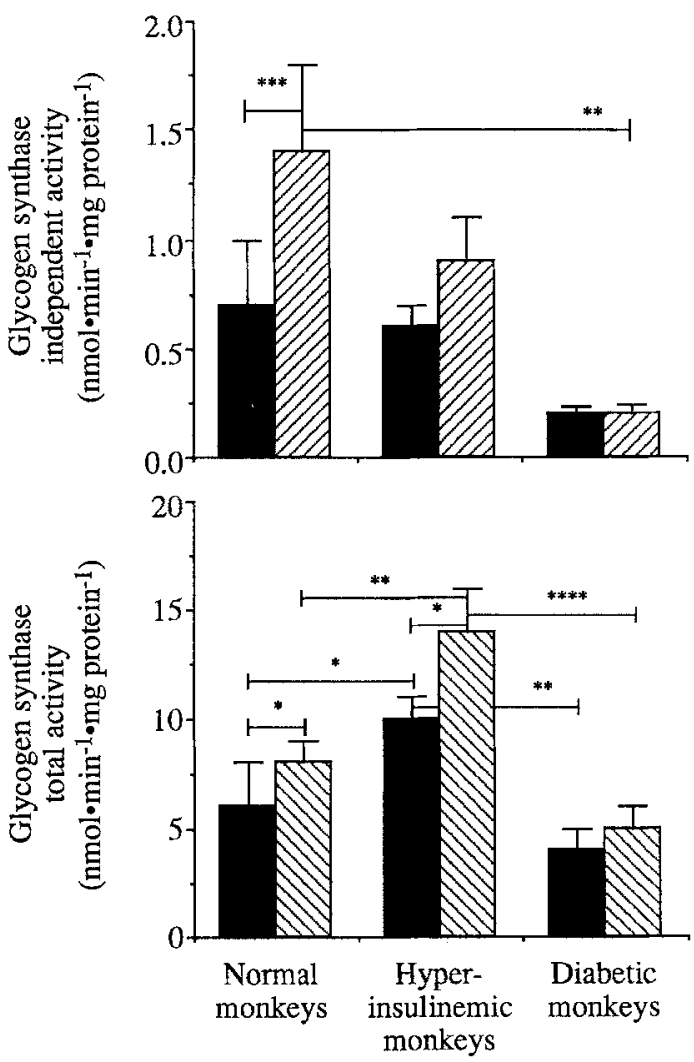

Fig. 1. Basal independent activity of glycogen synthase vs insulinstimulated independent activity of glycogen synthase (upper panel) and basal total activity of glycogen synthase vs insulin-stimulated total activity of glycogen synthase (lower panel) in the three groups of monkeys: normal $(n=11)$, hyperinsulinaemic $(n=8)$ and impaired glucose tolerant/Type 2 diabetic $(n=8)$. Basal, $\square$; insulinstimulated, $\mathbb{S}^{*} p<0.05, * * p<0.01$, *** $p<0.005, * * * * p<0.001$. Data are expressed as mean \pm SEM 
Table 2. Basal (B) vs insulin-stimulated (I-S) glycogen phosphorylase (GP) fractional velocity (GPAR), active (GPa) and total (GPT) activities and protein content in adipose tissue

\begin{tabular}{|c|c|c|c|c|c|c|}
\hline & \multicolumn{2}{|c|}{$\begin{array}{l}\text { Group } 1 \\
\text { (Normal, } n=11 \text { ) }\end{array}$} & \multicolumn{2}{|c|}{$\begin{array}{l}\text { Group } 2 \\
\text { (Hyperinsulinaemic, } n=8 \text { ) }\end{array}$} & \multicolumn{2}{|c|}{$\begin{array}{l}\text { Group } 3 \\
\text { (Impaired glucose tolerant/ } \\
\text { Type } 2 \text { diabetic, } n=8 \text { ) }\end{array}$} \\
\hline & $\bar{B}$ & $\mathrm{I}-\mathrm{S}$ & $\bar{B}$ & I-S & $\bar{B}$ & $\mathrm{I}-\mathrm{S}$ \\
\hline GPAR & $46 \pm 8$ & $48 \pm 7$ & $37 \pm 3$ & $38 \pm 3$ & $40 \pm 7$ & $47 \pm 5$ \\
\hline$(\%)$ & $(19-80)$ & $(20-77)$ & $(25-50)$ & $(29-49)$ & $(20-85)$ & $(37-81)$ \\
\hline $\begin{array}{l}\mathrm{GPa} \\
\left(\mathrm{mmol} \cdot \mathrm{min}^{-1} \cdot \mathrm{mg} \text { protein }^{-1}\right)\end{array}$ & $\begin{array}{l}0.04 \pm 0.01 \\
(0.01-0.11)\end{array}$ & $\begin{array}{l}0.04 \pm 0.01 \\
(0.02-0.10)\end{array}$ & $\begin{array}{l}0.04 \pm 0.01 \\
0.03-0.09)\end{array}$ & $\begin{array}{l}0.06 \pm 0.01^{\mathrm{a}} \\
(0.03-0.11)\end{array}$ & $\begin{array}{l}0.03 \pm 0.01 \\
(0.01-0.05)\end{array}$ & $\begin{array}{l}0.04 \pm 0.01 \\
(0.02-0.09)\end{array}$ \\
\hline $\begin{array}{l}\text { GPT } \\
\left(\mathrm{mmol} \cdot \mathrm{min}^{-1} \cdot \mathrm{mg} \text { protein }{ }^{-1}\right)\end{array}$ & $\begin{array}{l}0.08 \pm 0.01^{\mathrm{b}} \\
(0.04-0.14)\end{array}$ & $\begin{array}{l}0.09 \pm 0.01^{\mathrm{a}, \mathrm{b}} \\
(0.04-0.13)\end{array}$ & $\begin{array}{l}0.12 \pm 0.01 \\
(0.07-0.17)\end{array}$ & $\begin{array}{l}0.15 \pm 0.02^{a} \\
(0.09-0.22)\end{array}$ & $\begin{array}{l}0.08 \pm 0.01^{b} \\
(0.04-0.12)\end{array}$ & $\begin{array}{l}0.08 \pm 0.01^{\mathrm{b}} \\
(0.05-0.13)\end{array}$ \\
\hline Protein $(\mathrm{g} / \mathrm{l})$ & $0.62 \pm 0.08$ & $0.52 \pm 0.08^{\mathrm{a}}$ & $0.48 \pm 0.06$ & $0.37 \pm 0.04$ & $0.65 \pm 0.11$ & $0.53 \pm 0.06$ \\
\hline
\end{tabular}

${ }^{a}$ Significantly different from basal by paired $t$-test, $p<0.05 ;{ }^{b}$ significantly different from Group 2 by multiple comparison, $p<0.01$.

Values shown are mean \pm SEM

tional velocity was not different in the hyperinsulinaemic monkeys $(n=8)(5 \pm 1$ vs $6 \pm 1 \%)$ or in the diabetic monkeys $(n=8)(5 \pm 1$ vs $5 \pm 2 \%)$. The basal and insulinstimulated independent activities of glycogen synthase also were not significantly different in the hyperinsulinaemic monkeys $\left(0.6 \pm 0.1\right.$ vs $0.9 \pm 0.2 \mathrm{nmol} \cdot \mathrm{min}^{-1} \cdot \mathrm{mg}$ protein $\left.^{-1}\right)$ or in the diabetic monkeys $(0.2 \pm 0.04$ vs $0.2 \pm$ $0.04 \mathrm{nmol} \cdot \mathrm{min}^{-1} \cdot \mathrm{mg}$ protein $\left.{ }^{-1}\right)$. The insulin-stimulated change in glycogen synthase fractional velocity was significantly higher in the normal group as compared to the hyperinsulinaemic and diabetic groups $(p<0.05$, respectively). The insulin-stimulated independent activity of glycogen synthase was significantly greater in the normal monkeys as compared to the diabetic monkeys $(p<0.01)$.

The hyperinsulinaemic monkeys had a significant increase in the insulin-stimulated dependent activity of glycogen synthase as compared to the basal activity $(9.6 \pm 1.0$ vs $13.6 \pm 2.1 \mathrm{nmol} \cdot \mathrm{min}^{-1} \cdot \mathrm{mg}$ protein $\left.{ }^{-1}, p<0.05\right)$. The basal and insulin-stimulated dependent activities were not different in the normal $(5.1 \pm 1.4$ vs $6.7 \pm 1.1 \mathrm{nmol}$. $\mathrm{min}^{-1} \cdot \mathrm{mg}$ protein $\left.{ }^{-1}\right)$ and diabetic monkeys $(3.8 \pm 0.8 \mathrm{vs}$ $4.9 \pm 1.1 \mathrm{nmol} \cdot \mathrm{min}^{-1} \cdot \mathrm{mg}$ protein $\left.{ }^{-1}\right)$. Both the basal and

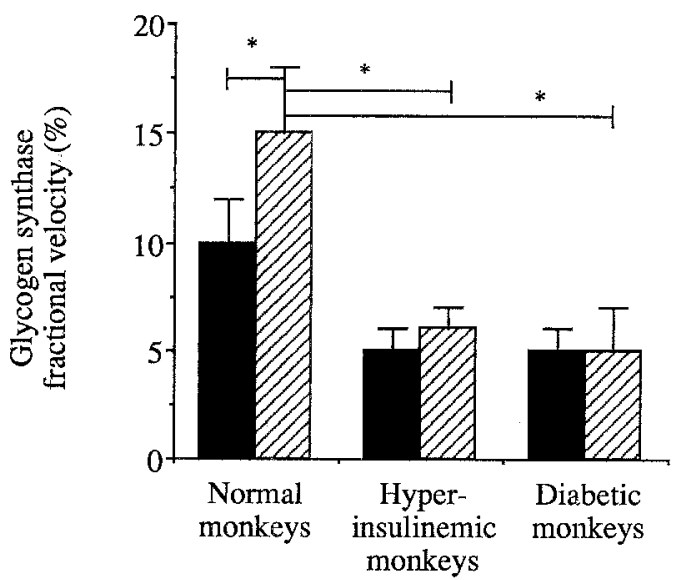

Fig.2. Basal glycogen synthase fractional velocity vs insulin-stimulated glycogen synthase fractional velocity in the three groups of monkeys: normal $(n=11)$, hyperinsulinaemic $(n=8)$ and impaired glucose tolerant/Type 2 diabetic $(n=8)$. Basal, $\square$; insulin-stimulated, $Z^{*} * p<0.05$. Data are expressed as mean \pm SEM insulin-stimulated dependent activities of glycogen synthase in the hyperinsulinaemic group were significantly greater than in the other two groups $(p<0.05$, respectively).

Significant increases in total glycogen synthase activity in response to in vivo insulin were found in both the normal monkeys ( $6 \pm 2$ vs $8 \pm 1 \mathrm{nmol} \cdot \mathrm{min}^{-1} \cdot \mathrm{mg}$ protein $\left.^{-1}\right)$ and the hyperinsulinaemic monkeys $(10 \pm 1$ vs $14 \pm 2$ $\mathrm{nmol} \cdot \min ^{-1} \cdot \operatorname{mg}$ protein $\left.{ }^{-1}\right)(p<0.05$, respectively $)$, however, there was no effect of insulin on total glycogen synthase activity in the diabetic monkeys $(4 \pm 1$ vs $5 \pm 1 \mathrm{nmol} \cdot \mathrm{min}^{-1} \cdot \mathrm{mg}$ protein $\left.{ }^{-1}\right)$. Both the basal and insulin-stimulated total activities of glycogen synthase in the hyperinsulinaemic group were significantly greater than in the other two groups ( $p<0.05$, respectively).

Change in adipose tissue glycogen synthase between groups. There was a progressive decrease in the change in glycogen synthase fractional velocity $(5 \pm 2 \%, 1 \pm 15 \%$, $0 \pm 2 \%$ ) and in the change in independent activity of glycogen synthase $\left(0.62 \pm 0.16 \mathrm{nmol} \cdot \mathrm{min}^{-1} \cdot \mathrm{mg}\right.$ protein ${ }^{-1}$, $0.31 \pm 0.16 \mathrm{nmol} \cdot \mathrm{min}^{-1} \cdot \mathrm{mg}$ protein ${ }^{-1}, \quad 0 \pm 0.06 \mathrm{nmol}$. $\mathrm{min}^{-1} \cdot \mathrm{mg}$ protein ${ }^{-1}$ ) from normal to diabetic, respectively. The normal monkeys had a significantly greater change in the independent activity of glycogen synthase as compared to the impaired glucose tolerant/diabetic monkeys $(p<0.01)$.

Glycogen phosphorylase activity. The basal and insulinstimulated activities of glycogen phosphorylase are shown in Table 2. The activity ratio of phosphorylase was not affected by insulin in any of the three groups. The insulinstimulated total activity of phosphorylase was significantly higher in the normal and hyperinsulinaemic monkeys compared to basal total phosphorylase activity. The insulin-stimulated active form of phosphorylase was significantly higher in the hyperinsulinaemic monkeys compared to the basal active form of phosphorylase activity. Both the basal and insulin-stimulated total activities of phosphorylase in the hyperinsulinaemic monkeys were significantly greater than in the normal and diabetic monkeys. 


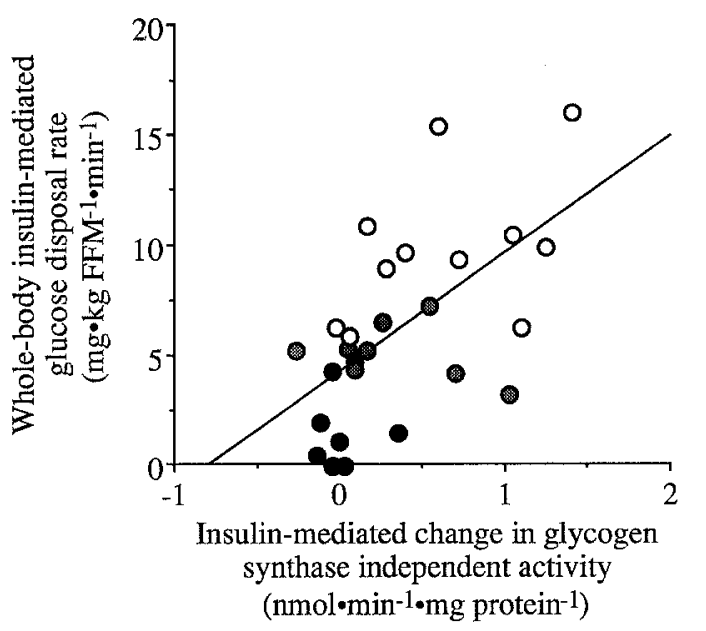

Fig. 3. The relationship ( $r=0.59, p<0.001)$ between the difference in adipose tissue glycogen synthase independent activity measured under insulin-stimulated (euglycaemic hyperinsulinaemic clamp) and basal (fasting) conditions and whole-body insulin-mediated glucose disposal rates in all 27 monkeys. Normal monkeys, $\mathrm{O}$; hyperinsulinaemic monkeys, impaired glucose tolerant/Type 2 diabetic monkeys, . FFM, Fat free mass

Insulin-mediated whole-body glucose disposal rates and glucose disappearance rates vs adipose tissue glycogen synthase activity. The relationship between the change in the independent activity of glycogen synthase and wholebody glucose disposal rates $(r=0.59, p<0.001)$ is shown in Figure 3. The relationship between the change in glycogen synthase fractional velocity in response to insulin and whole-body glucose disposal rates was also significant $(r=0.44, p<0.02)$. The relationship between the change in the independent activity of glycogen synthase and the change in the fractional velocity of glycogen synthase was $r=0.68, p<0.001$. The change in both the fractional velocity and the independent activity of glycogen synthase were also correlated with glucose disappearance rates, a measure of glucose tolerance $(r=0.42, p<0.05 ; r=0.56$, $p<0.01$, respectively).

Adipose tissue glycogen synthase activity and body weight, percent body fat and age. Neither the change in glycogen synthase fractional velocity nor the change in the independent activity of glycogen synthase in response to insulin was correlated with body weight. The change in glycogen synthase fractional velocity in response to insulin was significantly inversely correlated with percent body fat $(r=-0.37, p=0.05)$, however, the change in the independent activity of glycogen synthase was not significantly related to percent body fat. Both the change in glycogen synthase fractional velocity and the change in the independent activity of glycogen synthase in response to insulin were significantly inversely correlated with age $(r=-0.38, p<0.05 ; r=-0.42, p<0.05$, respectively). Both age and body fat, however, were confounded by diabetic status since the diabetic animals were older and had a higher percentage of body fat than the normal monkeys. One-way analysis of covariance demonstrated that body fat did not significantly contribute to the differences in insulin-mediated change in glycogen synthase frac- tional velocity found between groups. Similarly, age did not significantly contribute to the differences in either the insulin-mediated change in glycogen synthase fractional velocity or the change in the independent activity of glycogen synthase found between groups.

\section{Discussion}

In vivo insulin action on subcutaneous abdominal adipose tissue glycogen synthase has not been previously reported in normal or diabetic subjects. Our purpose in examining, in adipose tissue, the activity of the rate-limiting enzyme in glycogenesis, glycogen synthase, under basal fasting and euglycaemic hyperinsulinaemic clamp conditions was three-fold. First, we sought to determine in vivo insulin action on adipose tissue glycogen synthase in normal monkeys, for example, whether insulin increased the conversion of the dependent form of glycogen synthase to the independent form and if this conversion was accompanied by an increase in total glycogen synthase activity. Secondly, we examined in vivo insulin action on adipose tissue glycogen synthase in monkeys which had spontaneously developed insulin resistance and in monkeys with Type 2 diabetes, and determined whether insulin action was abnormal in either of these two groups compared to the normal monkeys. Thirdly, we were interested in the relationship between insulin activation of adipose tissue glycogen synthase and whole-body insulin-mediated glucose disposal rates, glucose disappearance rates, and percent body fat in monkeys that varied widely in insulin resistance, glucose tolerance and degree of obesity.

In subcutaneous adipose tissue from normal rhesus monkeys, in vivo insulin significantly increased the fractional velocity and the independent activity of glycogen synthase over basal activity. The total activity of glycogen synthase was also significantly increased by insulin in these normal monkeys. The increase in total glycogen synthase activity can be attributed to an increase in the independent activity of glycogen synthase, since the dependent activity of glycogen synthase was not significantly different between basal and insulin-stimulated conditions. In normal human subjects as well, an increase in total glycogen synthase activity has been reported by Mandarino et al. [17] in isolated adipocytes prepared from subcutaneous adipose tissue and treated in vitro with insulin. In adipocytes prepared from normal rat epididymal tissue, however, in vitro insulin increased the activity of glycogen synthase without an effect on total enzyme activity $[2,16]$. Insulin action may, therefore, be different in the different depots of adipose tissue. Furthermore, rodents may differ from primates.

Insulin did not activate adipose tissue glycogen synthase over basal levels in the hyperinsulinaemic monkeys as measured by the fractional velocity or the independent activity of the enzyme. Insulin did significantly increase the total activity of glycogen synthase as compared to basal in this group of monkeys which was accompanied by a significant increase in the dependent activity of glycogen synthase. Both the basal and insulin-stimulated total and dependent activities were significantly greater in the 
hyperinsulinaemic insulin-resistant group than in the other two groups. In the hyperinsulinaemic monkeys, the high fasting concentrations of insulin may be sufficient to increase the total enzyme activity but may have no effect on converting the dependent form of the enzyme to the independent form. Even at supra-physiological levels of insulin the enzyme appears to be "locked" in the dependent form. By contrast, Mandarino et al. [17] have reported no defect of in vitro insulin-activation of adipocyte glycogen synthase in obese human subjects (hyperinsulinaemic) as compared to normal subjects. The discrepancy between our results and those from Mandarino and colleagues may be due to the different methods used, i. e. in vivo vs in vitro insulin and fresh adipose tissue vs adipocytes. In agreement with our findings, however, Mandarino et al. [17] have reported an increase in total activity of glycogen synthase in obese humans in response to in vitro insulin.

Insulin appeared to have a similar effect on increasing the total activity of adipose tissue glycogen phosphorylase in the normal and hyperinsulinaemic monkeys as it did on the total activity of glycogen synthase. Insulin was without effect on changing the activity ratio of phosphorylase in any of the three groups of monkeys studied. Interestingly, both the basal and insulin-stimulated total activities of adipose tissue phosphorylase in the hyperinsulinaemic monkeys were significantly greater than in the normal and diabetic monkeys, as was shown for glycogen synthase in these same monkeys. In the insulin-stimulated samples from the hyperinsulinaemic monkeys, the increase in total phosphorylase was accompanied by a significant increase in the active form of phosphorylase as compared to basal activity. These findings in the hyperinsulinaemic monkeys further support the hypothesis that insulin action at the adipose tissue, at least on activating glycogen synthase and inhibiting glycogen phosphorylase, is defective long before the onset of overt diabetes.

In the impaired glucose tolerant and diabetic monkeys, glycogen synthase fractional velocity, independent and total activities of glycogen synthase were unchanged before and after insulin. The basal activities of glycogen synthase (fractional velocity, independent and total glycogen synthase activity) were not significantly different in the impaired glucose tolerant/diabetic group as compared to the normal group although the insulin-stimulated fractional velocity and independent activity of glycogen synthase in the diabetic monkeys were significantly lower than in the normal monkeys. These findings are in contrast with the observations of Mandarino et al. [17] who demonstrated an increase in total and independent activities and an increase in fractional velocity in response to in vitro insulin in adipocytes from humans with Type 2 diabetes. As noted above, these differing results between the monkey and human studies may relate to important differences in our protocol and that of Mandarino et al.

The change in adipose tissue glycogen synthase in response to in vivo insulin was significantly correlated with whole-body insulin-mediated glucose disposal rates and glucose disappearance rates. This is the first report of a relationship between in vivo insulin action on adipose tissue glycogen synthase and insulin-mediated glucose disposal rates. During a euglycaemic hyperinsulinaemic clamp, the primary site for glucose disposal is the muscle [39], and we have previously shown a relationship between glucose disposal rate and glycogen synthase activation by insulin in muscle [23]. Likewise, reduced insulin-mediated glucose disposal rates in insulin resistance and Type 2 diabetes have been attributed to a defect in the muscle $[39,40]$. The adipose tissue is believed to contribute very little to insulin resistance during the euglycaemic hyperinsulinaemic clamp [40]; hence, it would appear that a defect in insulin activation of glycogen synthase in adipose tissue would not contribute significantly to the reduced whole-body insulin-mediated glucose disposal rates. Nevertheless, the defect in insulin action on muscle glycogen synthase that is responsible for reduced insulin-mediated glucose disposal rates in insulin resistance is also present in adipose tissue.

In summary, insulin activated glycogen synthase in adipose tissue from normal rhesus monkeys by increasing the total and independent activities of glycogen synthase and the percent independent to total activity (fractional velocity). In the hyperinsulinaemic monkeys, basal fasting insulin increased total activity without increasing the independent activity of glycogen synthase as compared to normal monkeys, and supra-physiological concentrations of insulin acted to increase total activity without increasing the independent activity of glycogen synthase as compared to basal activities in the hyperinsulinaemic monkeys. Insulin had no covalent effect on adipose tissue glycogen synthase from impaired glucose tolerant and diabetic monkeys. We conclude that insulin action on glycogen synthase in adipose tissue is defective long before the onset of overt Type 2 diabetes in rhesus monkeys.

Acknowledgements. The authors gratefully acknowledge the expert technical assistance of Mrs. T. Alexander, Ms S. Fluck, Mrs. D. Roper and Dr. Z. Huang during the clamp procedures and the expert animal care provided by Mr. W. Evans and Ms S. Bell. We are also indebted to Dr. J. Larner and Dr. C.F. W. Schwartz for advice concerning the glycogen synthase assay and to Dr. A.J.Smalley and Dr. K.Stump for advice concerning anaesthesia.

\section{References}

1. Villar-Palasi C, Larner J (1960) Insulin-mediated effect on the activity of UDPG-glycogen transglucosylase of muscle. Biochim Biophys Acta 39: 171-173

2. Lawrence JC Jr, Guinovart JJ, Larner J (1977) Activation of adipocyte glycogen synthase by insulin. J Biol Chem 252: 444-450

3. Golberg ND, Villar-Palasi C, Sasko H, Larner J (1967) Effects of insulin treatment on muscle 3',5'-cyclic adenylate levels in vivo and in vitro. Biochim Biophys Acta 148: 665-672

4. Chiasson J, Dietz MR, Shikama H, Wootten M, Exton JH (1980) Insulin regulation of skeletal muscle glycogen metabolism. Am J Physiol 239: E69-E74

5. Kruszynska YT, Home PD, Alberti KGMM (1987) Insulin insensitivity and skeletal muscle enzyme activities in response to overinsulinization in the rat. Metabolism 36: 281-285

6. Le Marchand-Brustel Y, Freychet P (1979) Effect of fasting and streptozotocin diabetes on insulin binding and action in the isolated mouse soleus muscle. J Clin Invest 64: 1505-1515

7. Chan TM, Dehaye JP (1981) Hormone regulation of glucose metabolism in the genetically obese-diabetic mouse (db/db): glucose metabolism in the perfused hindquarters of lean and obese mice. Diabetes 30: 211-218 
8. Sheorain VS, Khatra BS, Soderling TR (1982) Hormonal regulation of skeletal muscle glycogen synthase through covalent phosphorylation. Fed Proc 41: 2618-2622

9. Evans DJ, Murray R, Kissebah AH (1984) Relationship between skeletal muscle insulin resistance, insulin-mediated glucose disposal, and insulin binding: effects of obesity and body fat topography. J Clin Invest 74: 1515-1525

10. Devlin JT, Horton ES (1985) Effects of prior high-intensity exercise on glucose metabolism in normal and insulin-resistant men. Diabetes 34: 973-979

11. Kruszynska YT, Petranyi G, Home PD, Taylor R, Alberti KGMM (1986) Muscle enzyme activity and insulin sensitivity in type 1 (insulin-dependent) diabetes mellitus. Diabetologia 29: 699-705

12. Mott DM, Lillioja S, Bogardus C (1986) Overnutrition induced decrease in insulin action for glucose storage: in vivo and in vitro in man. Metabolism 35: 160-165

13. Mikines KJ, Sonne B, Tronier B, Galbo H (1989) Effects of acute exercise and detraining on insulin action in trained men. J Appl Physiol 66: 704-711

14. Okubo M, Bogardus C, Lillioja S, Mott DM (1989) Adenosine 3',5'-monophosphate-dependent protein kinase activity decreases in human muscle after insulin infusion. J Clin Endocrinol Metab 69: 798-803

15. Castillo CE, Katz A, Spencer MK, Yan Z, Nyomba BL (1991) Fasting inhibits insulin-mediated glycolysis and anaplerosis in human skeletal muscle. Am J Physiol 261: E598-E605

16. Hope-Gill HF, Kissebah AH, Clarke P, Vydelingum N, Tulloch B, Fraser TR (1976) Effects of insulin and procaine hydrochloride on glycogen synthetase activation and adipocyte calcium flux: evidence for a role of calcium in insulin activation of glycogen synthetase. Horm Metab Res 8: 184-190

17. Mandarino LJ, Madar Z, Kolterman OG, Bell JM, Olefsky JM (1986) Adipocyte glycogen synthase and pyruvate dehydrogenase in obese and type 2 diabetic subjects. Am $\mathbf{J}$ Physiol 251: E489-E496

18. Wright KS, Beck-Nielsen H, Kolterman OG, Mandarino LJ (1988) Decreased activation of skeletal muscle glycogen synthase by mixed-meal ingestion in NIDDM. Diabetes 37:436-440

19. Johnson AB, Argyraki M, Thow JC, Broughton D, Jones IR, Taylor R (1990) Effects of intensive dietary treatment on insulinstimulated skeletal muscle glycogen synthase activation and insulin secretion in newly presenting type 2 diabetic patients. Diabetic Med 7: 420-428

20. Johnson AB, Argyraki M, Thow JC et al. (1991) Impaired activation of skeletal muscle glycogen synthase in non-insulin-dependent diabetes mellitus is unrelated to the degree of obesity. Metabolism 40: 252-260

21. Johnson AB, Argyraki M, Thow JC et al. (1991) The effect of sulfonylurea therapy on skeletal muscle glycogen synthase activity and insulin secretion in newly presenting type 2 (non-insulin-dependent) diabetic patients. Diabetic Med 8:243-253

22. Damsbo P, Vaag A, Hother-Nielsen O, Beck-Nielsen H (1991) Reduced glycogen synthase activity in skeletal muscle from obese patients with and without type 2 (non-insulin-dependent) diabetes mellitus. Diabetologia 34:239-245

23. Ortmeyer HK, Bodkin NL, Larner J, Hansen BC (1991) Insulin resistance and decreased insulin-mediated activation/inactivation of skeletal muscle glycogen synthase and phosphorylase activity in NIDDM is caused by defective release/generation of putative insulin mediator. Diabetes 40: 240 A (Abstract)

24. Kida Y, Esposito-Del Puente A, Bogardus C, Mott DM (1990) Insulin resistance is associated with reduced fasting and insulinstimulated glycogen synthase phosphatase activity in human skeletal muscle. J Clin Invest 85: 476-481
25. Kida X, Nyomba BL, Bogardus C, Mott DM (1991) Defective insulin response of cyclic adenosine monophosphate-dependent protein kinase in insulin-resistant humans. $\mathrm{J}$ Clin Invest 87 : 673-679

26. Vaag A, Henriksen JE, Beck-Nielsen H (1992) Decreased insulin activation of glycogen synthase in skeletal muscles in young nonobese Caucasian first-degree relatives of patients with non-insulin-dependent diabetes mellitus. J Clin Invest 89: 782-788

27. Antwi D, Youn JH, Shargill NS, Lesikar DD, Kaslow HR (1988) Regulation of glycogen synthase in muscle and adipose tissue during fasting and refeeding. Am J Physiol 254: E720-E725

28. Hansen BC, Jen K-LC, Schwartz J (1988) Changes in insulin responses and binding in adipocytes from monkeys with obesity progressing to diabetes. Int J Obesity 12: 433-443

29. National Institutes of Health (1985) U.S. Department of Health and Human Services. Committee on Care and Use of Laboratory Animals. Publication No. (NIH) 85-23

30. Hansen BC, Bodkin NL (1986) Heterogeneity of insulin responses: phases leading to type 2 (non-insulin-dependent) diabetes mellitus in the rhesus monkey. Diabetologia 29:713-719

31. National Diabetes Data Group (1979) Classification and diagnosis of diabetes mellitus and other categories of glucose intolerance. Diabetes 28: 1039-1057

32. Bodkin NL, Metzger BL, Hansen BC (1989) Hepatic glucose production and insulin sensitivity preceding diabetes in monkeys. Am J Physiol 256: E676-E681

33. Hansen BC, Bodkin NL (1990) $\beta$-cell hyperresponsiveness: earliest event in development of diabetes in monkeys. Am J Physiol 259: R612-R617

34. Pace N, Kline L, Schachman HK, Harfenist M (1947) Studies on body composition. IV. Use of radioactive hydrogen for measurement in vivo of total body water. J Biol Chem 168: 459-469

35. Hayashi M, Floyd JC Jr, Pek S, Fajans SS (1977) Insulin, proinsulin, glucagon and gastrin in pancreatic tumors in the plasma of patients with organic hyperinsulinism. J Clin Endocrinol Metab 44: 681-694

36. Guinovart JJ, Salavert A, Massague J, Ciudad CJ, Salsas E, Itarte E (1979) Glycogen synthase: a new activity ratio assay expressing a high sensitivity to the phosphorylation state. FEBS Lett 106: 284-288

37. Bradford MM (1976) A rapid and sensitive method for the quantitation of microgram quantities of protein utilizing the principle of protein-dye binding. Anal Biochem 72: 248-254

38. Glass GV, Hopkins KD (1984) Multiple comparisons. In: Osterberg M, Bernardi F (eds) Statistical methods in education and psychology. Prentice-Hall, Inc., New Jersey, pp 368-400

39. DeFronzo RA, Gunnarsson R, Björkman O, Olsson M, Wahren J (1985) Effects of insulin on peripheral and splanchnic glucose metabolism in noninsulin-dependent diabetes mellitus. J Clin Invest $76: 149-155$

40. Marin P, Rebuffe-Scrive S, Smith U, Björntorp P (1987) Glucose uptake in human adipose tissue. Metabolism 36: 1154-1160

Received: 6 July 1992

and in revised form: 22 October 1992

Dr. H.K. Ortmeyer

Obesity and Diabetes Research Center

University of Maryland at Baltimore

10 S. Pine St., Room 6-00

Baltimore, MD 21201

USA 